\title{
H2BC21 Gene
}

National Cancer Institute

\section{Source}

National Cancer Institute. H2BC21 Gene. NCI Thesaurus. Code C162975.

This gene is involved in packaging DNA into chromatin and antimicrobial activity. 